\title{
Unequal Neighbours? A French-German Comparison of Family Size Intentions
}

\author{
Kerstin Ruckdeschel, Anne Salles, Sabine Diabaté, Laurent Toulemon, \\ Arnaud Régnier-Loilier
}

\begin{abstract}
The neighbouring countries France and Germany show very different levels of fertility. Differences also exist between the two regions of East and West Germany. The aim of this paper is to help close a remaining gap in explaining these differences by applying a cultural concept of role models. Data is based on the German survey "Family-related role models" (2012) and the French survey "Situation de couple, intentions de fécondité et opinions sur la famille", ELIPSS (2013) offering a new approach to measuring the impact of social norms. The analysis uses multinomial logistic regression. We identified role models regarding the acceptance of childlessness on the one hand and large families on the other, as well as regarding the link between marriage and parenthood and the importance of financial security, suggesting different fertility-related cultures in France and Germany. There is a strong predominance of one general role model in France - that of having at least two children. In Germany, in contrast, there is a dominant role model - the two child family - but there are also several less central role models. The dominant model in France even leads to a sort of self-stigmatisation of individuals who want to stay childless, whereas childlessness is generally accepted in Germany. Role model differences between East and West Germany show a lower acceptance of large families and a higher acceptance of single-child families in the East. Our results highlight the importance of role models for fertility intentions as well as the relevance of cultural dimensions when studying the impact of the institutional framework on fertility.
\end{abstract}

Keywords: France $\cdot$ Germany $\cdot$ Role model $\cdot$ Intended family size $\cdot$ Norms $\cdot$ Values • Fertility · Family policy 


\section{Introduction}

With regard to fertility, France and Germany are often cited as two unequal neighbours (e.g. Salles et al. 2010; Fagnani 2002). France is a country with one of the highest fertility rates in Europe, while Germany has one of the lowest. This gap is usually explained by structural factors, especially work-life balance measures such as childcare facilities. Significant research has revealed a link between family policy aimed at reconciling work and family life, and the comparatively higher fertility levels in France and the Nordic countries (Gauthier 2007; McDonald 2005; Hantrais 2004). However, structural factors alone cannot explain the gap between France and Germany. The German government has implemented various reforms to help women combine work and family starting with the expansion of day-care for children under the age of three in 2004 (Bujard 2011). Even though the fertility rate has increased in Germany in recent years, it still remains at a comparatively low level. Germany is one of the few countries in Europe with a relatively high labour market participation of mothers, a rate of small children in day care which is EU average, and a low fertility level. In fact, several studies observe a limited effect of policy measures on fertility (Luci-Greulich/Thévenon 2013; Toulemon et al. 2008).

As research shows, cultural aspects additionally explain why the two neighbours differ in their fertility structure (Ruckdesche/ 2012; Salles et al.2010; Fagnani 2002) and could perhaps shed some light on the limited effect of family policy reforms in Germany. While there is strong social pressure to become a parent in France (Debest/Mazuy 2014), a culture of childlessness seems to be emerging in Germany (Dorbritz 2008; Sobotka 2008). To a lesser extent, such cultural differences can be found within Germany as well, i.e. between East and West Germany. Especially regarding norms and practices concerning the work-life balance, East Germany seems to have more in common with France than with West Germany (BMFSFJ 2015). In other words, the differences in fertility outcomes between France, West and East Germany might also be linked to "fertility-related norms" (Liefbroer et al. 2015; Liefbroer/Billari 2010). Social influence, defined here as the disposition to comply with widely accepted social norms, does indeed explain why attitudes towards fertility do not keep pace with social reforms or economic changes. This in turn explains why it may take time for family policy reforms to have an impact on fertility outcomes (Salles et al. 2010; Rossier/Bernardi 2009). However, examining the link between social norms and fertility has proven to be difficult because of a lack of available data.

The aim of this paper is to close remaining gaps in explaining fertility differences by applying a cultural concept of role models. ${ }^{1}$ In order to analyse the impact of social norms and social context, we operationalised the concept on both the individual and the societal levels. The societal level is included by the new concept of "individual perceptions of general opinion". In the survey we carried out, respondents

1 These role models refer to "guiding principles". 
were not only asked about their personal opinion on social norms, but also what they believe the broader population expects, in order to compare personal with perceived general opinion and to link these opinions to fertility intentions. Using this concept, we compare fertility-related role models for childlessness, large families, partnership and traditional role models in France and East and West Germany on the individual and societal levels. In a second step, we analyse how these different role models on the individual and societal levels correlate with intended final parity.

\section{Fertility trends and Family Policy in Germany and France}

\section{Fertility Trends}

Since the end of World War II, fertility has continuously remained at a higher level in France than in Germany. While the gap was widening between 2000 and 2010, it is now decreasing with the total fertility rate (TFR) rising slightly in Germany and seeming to be slightly declining in France. ${ }^{2}$ Nevertheless, the total fertility rate is currently about 30 percent higher in France than in Germany (see Fig. 1). While the total fertility rate was very low in East Germany after reunification, it is now slightly

Fig. 1: Total fertility rates in France and (unified) Germany, 1960-2016

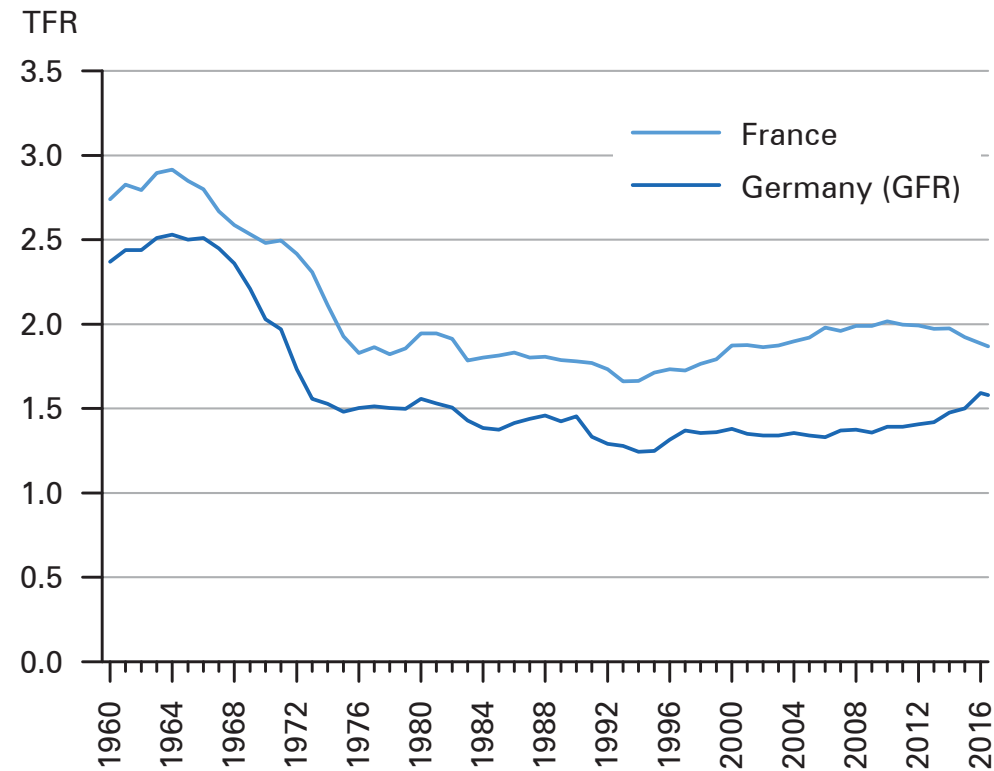

Source: Own calculations (Destatis 2017, 2018; INSEE 2018)

2 The decline in the number of births seems to have been accelerating in France since the second half of 2014. According to preliminary data, the total fertility rate fell to 1.88 in 2017 , compared to 2.00 in 2014, the lowest level since 1999 (Papon/Beaume/ 2018). 
higher than in West Germany. It is worth pointing out that the TFR is quite volatile in the short term, and therefore we avoid statements about future trends. We use TFR as a measure because it is the most up-to-date indicator of developments in fertility available.

Among other factors, the TFR gap between Germany and France can be explained by lower childlessness rates and a higher incidence of large families in France (Köppen et al. 2017; Kreyenfeld/Konietza 2017; Bujard/Sulak 2016; Hornung 2011; Prioux 2007). Of all women born between 1968 and 1972, nearly 30 percent have three children or more in France, compared to less than 17 percent in Germany (see Fig. 2). France also has a lower share of women with a single child.

While the total fertility rate is nearly the same in both parts of Germany, the distribution of mothers by parity remains quite different. 36 percent of women born between 1968 and 1972 have a single child in East Germany, compared to 22 percent in West Germany (and 18 percent compared to France in the case of women born in 1970). In East Germany, there are nearly as many women with a single child as with two children, but large families with three and more children are rarer. Nevertheless, the total fertility rate is actually slightly higher in the eastern part of the country, since childlessness is less common than in West Germany.

Non-marital births are least frequent in West Germany: In 2015, less than 30 percent of births occurred out of wedlock compared to 58 percent in East Germany (BiB 2017) and 59 percent in France (Eurostat 2017). This discrepancy may partly be

Fig. 2: Distribution of German and French women born between 1968 and 1972 by parity (in \%)

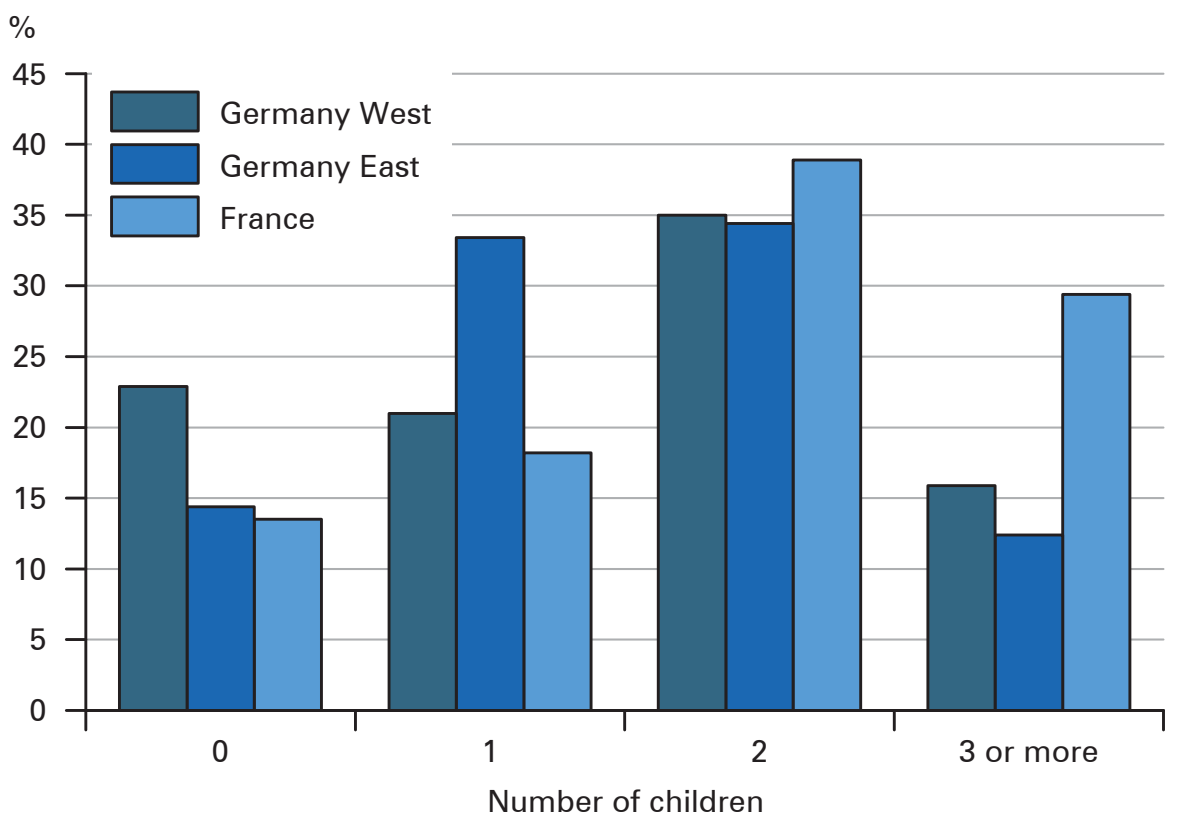

Source: Statistisches Bundesamt 2009; Köppen et al. 2017 
related to family policy. In Germany, financial advantages linked to marriage - e.g. tax benefits - are much higher than in France. As many women reduce working hours after birth or even stop working for some time, marriage provides an important factor of financial security for them. However, this also leads to more traditional gender roles and income gaps within a relationship. Therefore, we find a strong link between marriage and having children, and also between having children and adherence to traditional gender roles (Salles 2016; Klärner 2015). In France, married couples benefit from the same incentive (quotient conjugal), but this is softened by a family tax splitting rule that includes children (quotient familial), and is not limited to married couples, which means that the incentive to marry is lower (Eide/man 2013). In East Germany on the other hand, family policy supporting unmarried mothers has encouraged parents to have their first child outside marriage and to postpone marriage. This trend weakened the link between children and marriage in the long term (Klärner 2015; Dorbritz 2008).

\section{Family Policy}

The differences in the demographic situation in the two countries have often been linked to family policies, which differ significantly. French family policy has a long tradition of supporting large families, which can be related to the low fertility prevailing in France from the late 18th century until the end of World War II. Financial support for families increases with the number of children and is especially high from the third child onwards. Parental leave is only one year for parents with one child, but three years for parents with at least two children, ${ }^{3}$ whereas there is no difference by parity in Germany. Similarly, in France only parents with at least two children are entitled to family allowance, which is notably higher for the third child, whereas in Germany the allowance is nearly the same for each child. Likewise, the French tax-splitting system benefits large families as it takes into account the number of children in the household and assigns greater weight from the third child onwards. Large families are also entitled to further child-related financial benefits.

Furthermore, both countries support family-work balance, albeit with some differences. France has a long tradition of promoting the reconciliation of work and family life through diversified childcare, financial support for external childcare, and all-day schooling. But for Germany, this is relatively new - Until the mid-2000s it was quite difficult for western German mothers to combine work and family. This was partly due to low childcare provision for children under the age of three, combined with three years of parental leave, and half-day schooling (Périvier 2004; Fagnani 2002). This situation is changing gradually. Following the recommendation of the European Union, the German government decided in 2005 to develop external

3 In France, parental leave is six months for each parent with one child. For parents with at least two children, parental leave is two years for one parent and one year for the other. As only 4 percent of fathers take parental leave in France, in practice this amounts to six months for the first child and two years starting from the second child, for the vast majority of families (data for 2013, OECD 2016). 
childcare and to encourage mothers to work. Parental allowance is only paid for one year so as to attract mothers back to the workforce after one year (rather than three). This requires the availability of childcare provision. Therefore, the German government extended financial support for daycare services for children under the age of three in 2005.

In conclusion, structure - defined here as laws and political reforms, resulting from a given cultural setting, and formed over decades - matters in both countries. The process of stabilisation or change of a given cultural setting is caused by its strong interaction with politics and behaviour. These settings in turn establish a certain gender culture and family conceptions.

\section{Theoretical Considerations and Hypotheses}

\subsection{Theoretical background}

Recently, the most popular approach in trying to explain changes and differences in family lives has been the rational choice framework. Despite successfully explaining some patterns, such as high fertility in countries with good public childcare as a result of low opportunity costs, other findings remain unclear in the context of this theory, such as persistant gender differences in the distribution of housework despite equal contributions to the household income (e.g. Aassve et al. 2014). Institutional approaches (e.g. Pfau-Effinger 2004, 1996) offer explanations for crossnational differences complementing structural with cultural arguments. We find this useful, and therefore employ the concept of role models for our comparison. The term "role model" is used in the sense of a "guiding image", derived from the German "Leitbild", meaning "an idea or a conception of how things in a certain context should be, work, or look like." (Lück et al. 2017: 64). The "role model" concept develops existing approaches further by describing cultural characteristics as sets of collectively shared conceptions and images of a "normal" status or process, in the sense that these are widespread, socially expected or personally desired. In this context, role models are to be seen as a "bundle of socially shared (mental or verbalised) conceptions of a desired or desirable and principally achievable future which are supposed to be realised by corresponding action" (Giese/ 2007: 245; translated by the authors). Role models may thus refer to family issues, such as the "normal" composition of a family or the "perfect" timing of when to have children. They are "typical societal ideal representations, norms and values regarding the family and the societal integration of women and men" (Pfau-Effinger 2004: 382). As we show, this definition is applicable in empirical research.

A role model can affect individual behaviour in three ways (Lück et al. 2017): (1) by the actor's motivation to put personal desires into practice (such as attitudes, preferences, or values), (2) by the motivation to fulfil social expectations and to avoid social exclusion (such as prescriptive norms referring to social pressure), and (3) by the unreflected following of routines or social practices in order to save time and effort (such as frames and scripts taken as common and self-evident; reducing 
complexity in decision-making). However, the concept of role models assumes that conceptions of normality mostly fulfil all three criteria simultaneously and that the criteria are interdependent. In this sense, the "role model" framework is more complex than most cultural concepts.

This also implies that role models take hold on both the micro and macro level. They are micro-level phenomena, because every individual has their own role models, which might differ from the role models of others. Therefore, differences in family-related behaviour can be explained on the micro level, referring to personal or individual role models. However, role models also tend to be shared by individuals within a society or a social group, and therefore can explain differences in behaviour on the macro level as collective or cultural role models.

These two types of role models simultaneously influence behaviour alongside rational reflection and decision-making, as well as in interaction with each other. However, individuals are not necessarily aware that they are following role models. They may well consider their behaviour to be the result of a personal decision (Rossier/Bernardi 2009). The influence of role models reproduces and stabilises the common patterns of family life and decelerates social change (such as the convergence of gender roles). Their influence is similar to norms which are one aspect of role models. Prescriptive and proscriptive norms - rigid expectations about how to behave and how not to behave, respectively - stabilise a social situation whereas permissive norms - allowances of certain behaviour - favour social change (Bernardi 2013). The wide acceptance of births outside marriage in France is an example of the latter.

In our comparison, we assume that role models at the individual and societal level differ between France and Germany and between the two German regions East and West. Explanations for these differences arise from structural differences and historical developments, which affected role models through different norms of childlessness, large families, gender, and partnership. The policy settings and their facets of pronatalism, conservatism and individualism in France and Germany should help to explain the differences in family-related norms. Therefore, we focus on individual role models on the one hand, and on perceived opinions in society on the other.

\subsection{Hypotheses}

\subsubsection{Family size-related factors}

Differing family sizes are one cause of the different fertility levels in France and Germany. Regarding the distribution by parity, the most striking differences between France and the two parts of Germany involve the occurrence of childlessness and of large families. Based on our theoretical concept, there should be particular role models within each region. It is not possible to relate role models and fertility outcomes over time with the available data, thus we focus on individual fertility intentions instead. This allows us to relate role models and the intended number of children in the current structural context in which these intentions are formed. 
We assume that in all three regions individuals are convinced of their personal role models and live according to them, which leads to the psychological effect of a reduction of dissonance between ideals and real life. Therefore, individuals who wish to remain childless are assumed to consider childlessness as something normal, while individuals who want to have at least three children see large families in a positive light. Conversely, the respective opposing intention is rejected (H1a). We further expect that intended childlessness is perceived as being accepted on a societal level in West Germany and to a lesser extent also in East Germany, but not socially accepted in France ( $\mathrm{H} 1 \mathrm{~b})$. Conversely, we assume that large families are socially accepted in France, whereas in West Germany and even more so in East Germany they are not $(\mathrm{H} 1 \mathrm{c})$.

\subsubsection{Partnership-related factors}

\section{Traditional values (attitudes towards marriage and gender roles)}

Another differentiating factor between the regions under study is the lower share of births out of wedlock in West Germany compared to France and East Germany, pointing to a higher appreciation of traditional values within partnerships. In West Germany, we therefore expect intended childlessness to be closely correlated with a rejection of marriage and traditional gender role models on the individual level. In France and East Germany on the other hand, no correlation should be visible (H2a). We further assume that the appreciation of marriage and traditional gender role models is combined with a higher intended final parity, i.e. three or more children, as having many children matches the traditional way of life in all three regions $(\mathrm{H} 2 \mathrm{~b})$.

\section{Financial security}

The impact of family policy is explored by accounting for the importance given to financial security in the context of partnership. With this indirect and rather crude measure, we attempt to capture the fact that financial security should be less important if families can rely on government support. In France, when individuals consider whether or not they want to have children, and if so how many, we expect less weight attached to their financial situation due to generous state aid. Nevertheless, the start of a family is a crucial point, because financial aid is only paid from the second child onwards. If there is any impact of financial security, it should take hold at the transition to the first child. In Germany, aid is less generous, and we therefore expect individuals to attach greater importance to personal financial security (H3a). These two expectations should also hold as societal opinions in the respective countries (H3b). 


\section{$4 \quad$ Data, methods and operationalisation}

The German survey "Family-related Leitbilder" (FLB) was carried out in 2012 by the Federal Institute for Population Research (BiB) as a telephone survey. ${ }^{4}$ The target population were people living in Germany between the ages of 20 and 39. It was designed to explore cultural aspects related to family issues and consisted of 5,000 respondents (3,986 in West Germany, 1,014 in East Germany). The French survey "Marital status, fertility intentions and family opinions" was conducted in 2013 as a pilot study carried out on tablets, as part of the ELIPSS panel (Longitudinal Internet Studies for Social Sciences). ${ }^{5}$ The sample was far smaller, 340 cases for the age group of 18-40-year-olds. The comparability of the two surveys is challenging with regard to sampling methods and general aims. Nevertheless, we have the advantage of similar questions on role models in both surveys, because parts of the original German survey were directly translated and implemented into the French panel. Both samples are weighted for socio-economic factors (Lück et al. 2013; Pilorin/Legleye 2018).

Our data offer new perspectives for comparing France and Germany regarding their family-related role models. They also offer a new method to operationalise the measurement of general opinion. For this purpose, we asked questions on two different levels: first, personal opinions of the respondent on family-related topics, and then the perception of societal norms on the same topic. In practice, this means that respondents were first asked about their personal opinion on an item, e.g. "Nowadays it is normal not to have children, do you personally agree?"6, and in a second step, they were asked "And what does the general public think about this topic?" The same response scale was used for both questions (Lück et al. 2013).

We chose items covering the issues of childlessness, large families, and partnership for our research question on the impact of family-related role models on fertility intentions. These items will be introduced in detail in the next section. In our operationalisation, we linked role models to fertility intentions and thereby compare groups with different final intended parity. Following Hagewen and Morgan (2005), we interpreted fertility intentions as a "proximate determinant" of actual behaviour, fully aware of the fact that it is not certain whether intentions will ultimately be realised. Since the data only offer a limited number of items to compare, we used single items as proxies for role models. We define final intended parity as the number of children a respondent already has plus the number of (additional) intended children plus pregnancies at the time of the interview (see e.g. Sobotka 2009; Liefbroer 2009). The non-response rate was high in the French survey, which reduced our sample size further. ${ }^{7}$ This might be due to the tablet survey design in France or

4 http://www.bib.bund.de/EN/Research/FB1_Family/FG11_Leitbild/fg11_node.html

5 https://cdsp.sciences-po.fr/en/ressources-en-ligne/ressource/fr.cdsp.ddi.elipss.2013.11.familles/

6 We used 4-level Likert items with the following choice of answers: "fully agree; rather agree; rather disagree; totally disagree".

7 See respective models. 
due to the fact that the items were originally designed for German respondents only. Therefore, we decided to analyse strongly reduced multivariate models controlling only for age, sex, partnership, and educational level. Furthermore, we dichotomized the opinion items in order to keep the number of cells in the model small enough to obtain stable results. We compared childless persons who wish to remain childless, persons with final intended parity one, and persons with final intended parity three or more with the most widely-intended two-child family. The French data allow for the exclusion of infertile persons, while this is not possible for the German data. As the sample size for Germany is much larger, the distortions due to this lack of information should be smaller than if it would have been the case for France. Due to the small sample size of the French survey, we calculated two models, one for the influence of family-related items and one for partnership-related items.

\section{Descriptive comparison - cultural dimensions of childlessness, large families and partnership}

Our findings (Table 1) confirm that childlessness seems to be accepted by individuals and perceived as unexceptional on the societal level in Germany. Surprisingly, we do not find great differences between the two German regions, although they differ greatly in the occurrence of childlessness (Fig. 2). In France on the other hand, it seems that respondents accept childlessness to a greater extent on the individual level than on the perceived societal level. However, the acceptance is significantly lower than in Germany in each case. The picture changes for the other extreme, the evaluation of large families (defined as three or more children), which was probed using the statement "it is wonderful to have many children." In France, large families seem to be widely accepted as something normal, not extraordinary. About half of the population agrees that having many children is wonderful. In Germany, on the other hand, there is a wide gap between individual and perceived societal acceptance. Large families are viewed positively on the individual level but are perceived to be not accepted at the societal level, and are moreover only regarded as an acceptable option for those parents who can cover the expenses. Indeed, large families are often stigmatised as being financially needy and for living on social welfare (Diabaté et al. 2015). In France, large families may be more widely accepted due to significant and long-standing institutional support. We also find differences within Germany. Larger families are more common in West than in East Germany. This fact is mirrored by the appreciation at the individual level: Approval of large families is greater in West than in East Germany. Finally, financial constraints for large families matter in Germany, whereas in France the notion of equal opportunities places the financial burden on the state in the eyes of the respondents.

The financial situation is also important when it comes to partnership. A good financial situation is more commonly perceived as a key to the success of a partnership in Germany than in France. However, the most prominent difference between the two countries is the importance given to children in the context of partnerships. Partnership seems to be much more strongly linked to children in Germany (both 


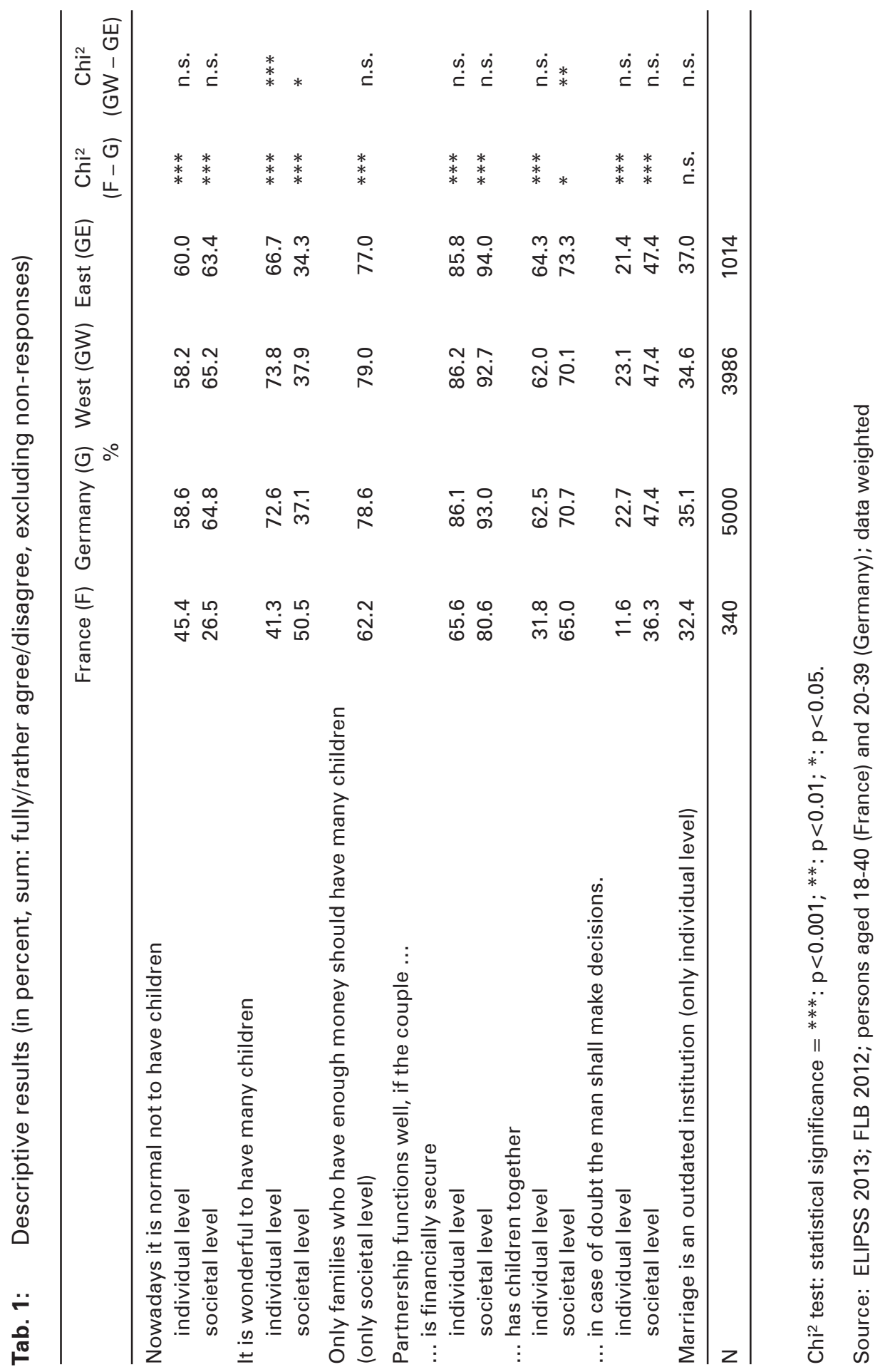


parts) than in France. Furthermore, there seems to be no strong difference between the countries when taking the acceptance of marriage as an indicator of traditionalism. However, the question of whether the man should take decisions in case of doubt reveals strong differences on the individual level, indicating that there is more equality in couples' decision-making in France.

\section{Associations between role models and fertility intentions}

In our next step, we link role models to fertility intentions using final intended parity as the dependent variable, and compare these groups to their role models. Due to different sample sizes, we find more significant effects for Germany than for France when comparing the influence of family-related items (Table 2). The data are crosssectional, so no causal effects can be deduced. The correlations relate current fertility intentions to current role models and show that there is an interrelation, though we cannot tell if there is a temporal aspect, i.e. whether one determines the other.

\subsection{Family size-related factors}

We expected to find a strong link between individual intentions and the corresponding opinion on role models. For Germany, this hypothesis is confirmed, i.e. individuals who wish to stay childless perceive childlessness as normal, while those who wish to have larger families perceive this as an acceptable route. Contrary to this, in France individuals who wish to remain childless do not consider childlessness as normal and also perceive their own intentions as being contrary to the broader social norm. This finding is similar to the outcomes of a qualitative study conducted by Charlotte Debest (2014, see also Debest/Mazuy 2014). The fact that we do not find any significant differences between the groups with different fertility intentions when it comes to the general norms about childlessness in France further confirms this finding. There seems to be a general social consensus that childlessness is undesirable, which is related to negative external circumstances, i.e. not having a partner, job-related constraints, or medical problems (Salles et al. 2010). The results are very different for Germany. In East and West, childless persons regard their life plan as normal, but perceive childlessness as not accepted in society more broadly. The same applies to persons with final intended parity one in West Germany. However, we find a different situation in East Germany, where one-child families are more frequent and are not seen as violating an accepted norm or role model. Regarding the appreciation of large families, our hypotheses on the individual level are confirmed in all three regions. The desire to have a large family is strongly correlated with the individual appreciation of children. In Germany, this hypothesis is also confirmed the other way around, i.e. persons not wanting to have children or only one child are personally not in favour of large families. We already found this relationship in the descriptive results (Table 1), where large families seem to be a highly controversial topic in both parts of Germany. Persons wanting large families see no societal support for their intentions, whereas those who do not want any children think large 


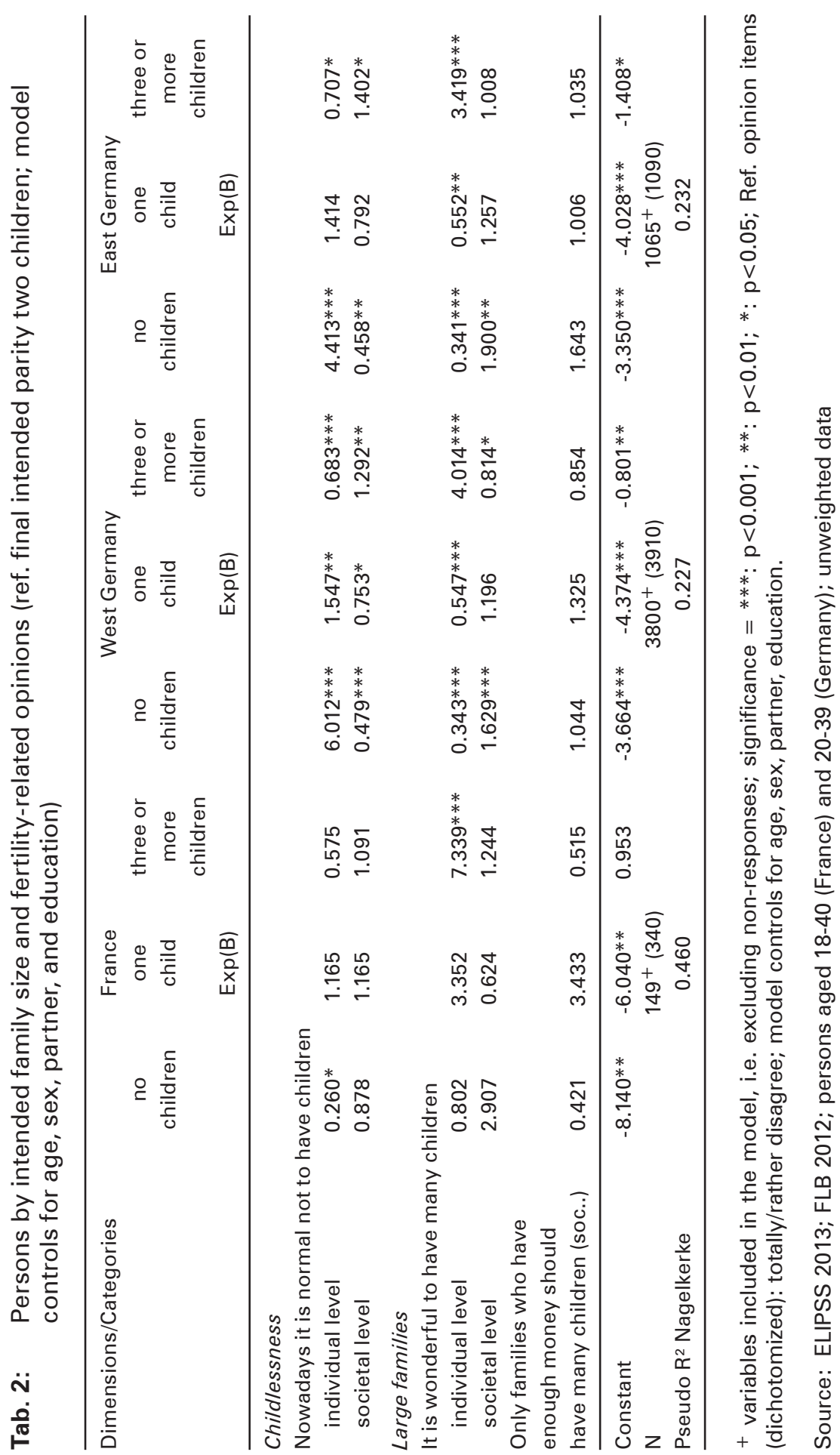


200 - Kerstin Ruckdeschel et al.

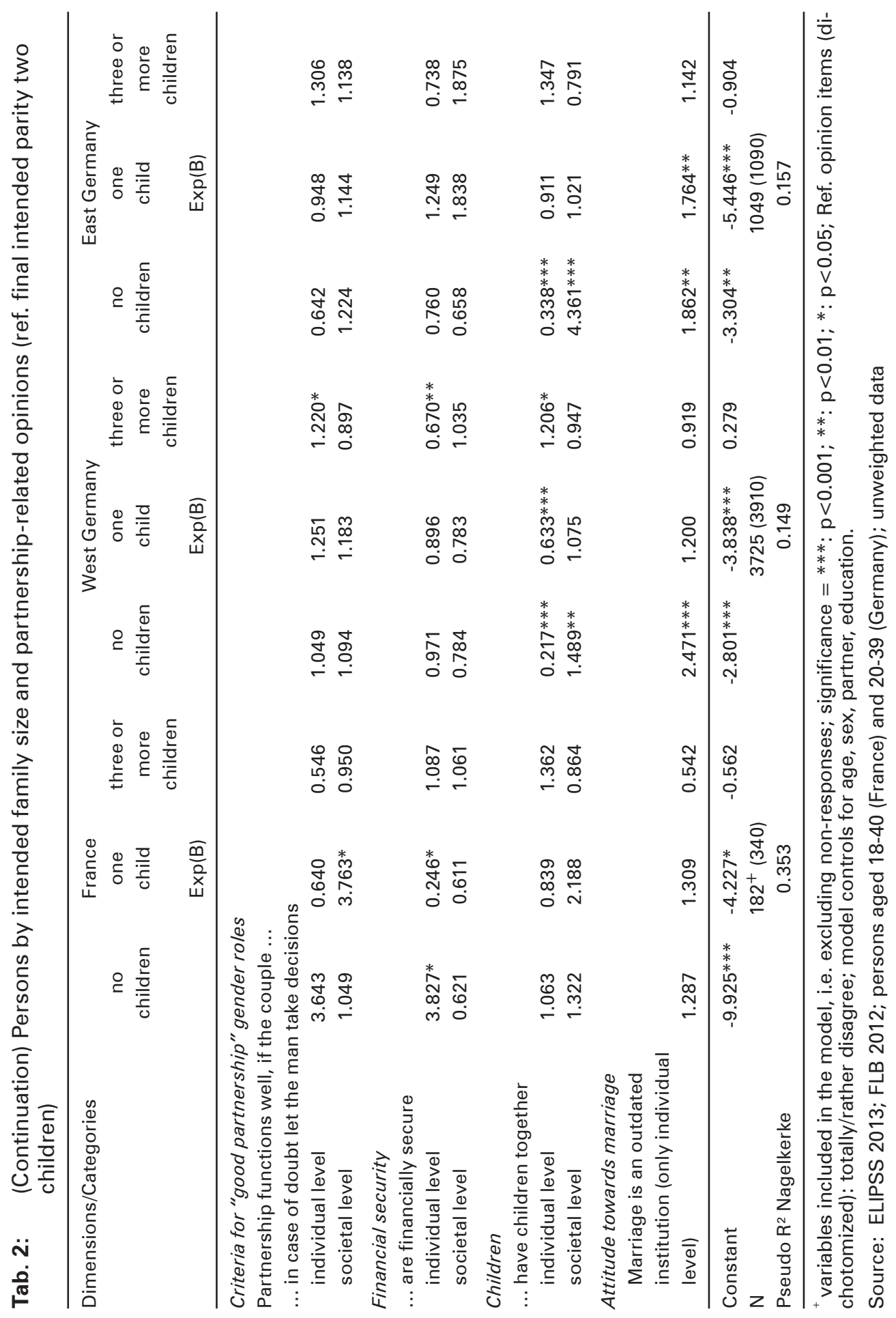


families are rather appreciated. While our findings support hypotheses $\mathrm{H} 1 \mathrm{~b}$ and $\mathrm{H} 1 \mathrm{c}$ on the acceptance of childlessness and large families, $\mathrm{H} 1 \mathrm{a}$ on the conformity of individual intentions and role models can only be confirmed for Germany.

\subsection{Partnership-related factors}

Regarding the influence of partnership-related items on fertility decisions, we again find different cultures in France and Germany. The belief that financial security is important for the functioning of a partnership closely correlates with not wanting children in France. In contrast, individuals with final intended parity one reject the importance of financial security. This also applies to West German respondents who want three or more children. This may be explained as a statement of attaching greater importance to the goal of having children than to financial security in both regions. In West Germany, the same group, i.e. people wanting a large family, opts for the man to take the leading role in a partnership, which can be interpreted as a more traditional idea of partnership.

Another important difference between both countries is that children and partnership are less strongly linked in France than in Germany. This is observable in both the descriptive results and the control variables, where having no partner is a strong determinant for intending to remain childless in both parts of Germany, but not in France. In East and West Germany, we find a strong rejection by individuals who want to stay childless of the idea that a partnership needs children in order to stabilise. Conversely, the reference group, i.e. respondents wanting two children, support the notion of children contributing to stable partnerships. This is also what individuals who want to stay childless perceive as a social norm in society. If having children is closely linked to the societal notion of a "good" partnership, then the preconditions for having children are different from France. If the connection between partnership and parenthood was seen as less strong by Germans, individuals might have children with a partner despite not being sure whether the partnership will last. An explanation for this different situation may be found in the fact that some parental benefits were legally linked to marriage in Germany for a long time. This legal link has been removed in recent years, i.e. children born out of wedlock now have the same rights as children born in a marriage, but the link remains strong as a role model. The strong link between partnership and children in Germany also reveals that financial constraints may be stronger than in France. The risk of falling into poverty when raising children as a single parent is higher in Germany than in France (Jaehrling et al. 2011). Finally, in both parts of Germany the group of intentionally childless persons is also characterised by their rejection of marriage, which supports the assumption of a strong link between marriage and children. Here, we find a significant difference between East and West Germany. Individuals wanting only one child reject marriage in East Germany, whereas in West Germany the dividing line seems to be that of wanting to have children at all. We interpret this as confirmation of the historically stronger separation of marriage and children in East Germany, where having one child does not necessarily imply marriage, as we explained in section 2.1. 
The results concerning the importance of marriage in West Germany compared to France and East Germany support $\mathrm{H} 2 \mathrm{a}$, but $\mathrm{H} 2 \mathrm{~b}$ is only confirmed for West Germany. We also did not find any well-founded evidence for the greater importance of financial security in Germany, i.e. for H3a and H3b. However, as hypothesized, financial problems seem to be an obstacle for parenthood in France, as financial aid only starts from the second child onwards.

\section{Discussion}

In this study, we aimed to close a research gap in explaining differences in fertility between France and Germany by applying a cultural concept of role models on a personal as well as societal level. In line with our hypotheses, we found role models suggesting different fertility cultures in France and Germany, whereas the differences between the two German regions were less pronounced than expected. In both countries, we find a strong two-child family norm. Furthermore, family formation in France seems to be easier and more self-evident, with fewer structural and cultural barriers than in Germany. However, the decision to start a family at all seems to be easier in Germany. We did not find many differences between East and West Germany, except for a higher rejection of large families and greater support for singlechild families in East Germany, which we expected because of a longer tradition of smaller families in the former GDR.

Regarding key features of fertility, the recognition of childlessness as a role model varies widely between the two countries. In Germany, childlessness seems to be an accepted way of living, unlike in France. Although there seems to be some acceptance at the individual level, childlessness is perceived as being contrary to the broader societal norm. This even leads to a sort of self-stigmatisation of individuals who do not intend to have children themselves. Another demographic key factor showing opposing results in the examined countries are large families. There seems to be general acceptance in France, whereas in Germany the situation is highly controversial. Large families are individually accepted as a role model, but are perceived as stigmatised in society. As a common feature in both countries, the intention to have a large family is mainly based on strong individual convictions which, in the case of Germany, even outrank financial concerns. Financial security is broadly associated with having a family in Germany and therefore is one basis of the role model. Another German peculiarity in comparison to France is the strong link between partnership and parenthood. The notion that parenthood must be embedded in a well-functioning, stable partnership seems to be stronger in Germany than in France. This interdependence may pose a barrier to start and extend a family. This also applies to the fact that having a family seems to be strongly associated with a traditional living arrangement for some groups, for whom this traditional arrangement is an unattractive option. To avoid this situation, they may prefer to remain childless.

Exploring these role models helps us understand the demographic situations in France and Germany, because they may influence personal decisions. Furthermore, 
they demonstrate the interdependence of cultural and structural factors. We are speaking of interdependence insofar as there is no direction in terms of cause and effect between incidence and social acceptance but a clear mutual dependency. A high percentage of large families in a society enhances their acceptance and makes them an eligible choice, as in France. A lower percentage has the opposite effect, which is true for East Germany, where the low occurrence of large families is connected to a negative image. The same applies to childlessness in France. Another aspect in this context are preconditions individuals associate with having a family, namely a solid financial basis and a stable partnership. While an uncertain financial situation may be a hindrance for founding a family in France, in Germany an unstable partnership could play this role.

We differentiated between role models on the individual and on the societal level. Usually, individuals are familiar with the role models of the society they live in and accept and follow them. When societal norms and individual behaviour differ, there are various ways to react: Individuals may be convinced of their personal role models and act on them. In West Germany, this concerns all groups who are outside the two-child-norm, i.e. individuals who want to remain childless, who want one child or three children or more. Their intentions are consistent with their personal role models, but they believe that society in general thinks differently. The same holds true for East Germany, except for individuals wanting one child, which can be explained by a strong general role model of one-child families in this region. Generally, these attitudes reveal a significant discrepancy between role models at the individual and at the societal level, but there is also a strong link between fertility intentions and individual perceptions. Individuals consider themselves as acting against the social norm, but nonetheless appreciate their own role models. In France, the situation is different: For individuals with no fertility intentions, role models at the individual and at the societal level are consistent, but oppose their personal intentions, which seems to be contradictory. This highlights the prominence of one overarching role model of having at least two children (in France), in contrast to one dominant and several less central role models (in Germany).

The way individuals react to non-corresponding role models shows significant cultural differences between Germany and France. In Germany, there seems to be a more individualistic approach. Individual role models are stronger than societal role models, which leads to a higher occurrence and consequently a higher acceptance of different family forms in general. However, it also leads to a higher distinction on the individual level, as everyone has to justify their choice of living arrangement in light of many possibilities. This results in more exclusive subgroups in society which may be an indicator for a segmentation of German society into separate family milieus, with little mutual appreciation. By contrast, we find a rather homogenous picture in France, indicating a more socialistic attitude. There seems to be one comprehensive dominating role model, namely that having children is self-evidently a good thing: childlessness is considered contrary to the societal norm; hence this role model may put pressure on people who are not sure whether they want to have children or not. 
This study highlights the importance of role models in fertility intentions and outcomes. Furthermore, it emphasizes the relevance of family role models prevailing in a given society when studying the link between institutional frameworks and fertility decisions. Thus, we provide new deep insights into the fertility cultures in France, East and West Germany. However, as our databases were two crosssectional surveys which differ in size and implementation, further research is necessary. International comparable panel data is needed to further investigate the causal relationships between role models and fertility behaviour.

\section{Acknowledgements}

The authors would like to thank the editor and two anonymous reviewers for their constructive comments and suggestions during the review process.

\section{References}

Aassve, Arnstein; Fuochi, Giulia; Mencarini, Letizia 2014: Desperate Housework: Relative Resources, Time Availability, Economic Dependency, and Gender Ideology Across Europe. In: Journal of Family Issues 35,8: 1000-1022 [doi: 10.1177/0192513X14522248].

Bernardi, Laura 2013: From Mothers to Daughters: Intergenerational Transmission of Fertility Norms. In: Ellingsaeter, Anne Lise; Jensen, An-Magritt; Lie, Merete (Eds.): The Social Meaning of Children and Fertility Change in Europe. London/New York: Routledge: 153-169.

BiB (Bundesinstitut für Bevölkerungsforschung - Federal Institute of Population Research) 2017: [http://www.bib-demografie.de/SharedDocs/Glossareintraege/EN/N/non marital_rate.html? $\mathrm{nn}=3214532,08.01 .2019]$.

BMFSFJ (Bundesministerium für Familie, Senioren, Frauen und Jugend) 2015: Familienbilder in Deutschland und Frankreich. Monitor Familienforschung 34. Berlin: BMFSFJ.

Bujard, Martin 2011: Family Policy and Demographic Effects: The Case of Germany. In: Demográfia 54,5: 56-78.

Bujard, Martin; Sulak, Harun 2016: Mehr Kinderlose oder weniger Kinderreiche? Eine Dekomposition der demografischen Treiber in unterschiedlichen Phasen des Geburtenrückgangs in Deutschland. In: Kölner Zeitschrift für Soziologie und Sozialpsychologie 68,3: 487-514 [doi: 10.1007/s11577-016-0373-6].

Debest, Charlotte 2014: Le choix d'une vie sans enfant. Rennes: Presses universitaires de Rennes, coll. "Le sens social ". In: Population 71: 759-761 [doi: 10.3917/ popu.1604.0759].

Debest, Charlotte; Mazuy, Magali 2014: Childlessness: a life choice that goes against the norm. In: Population \& Sociétés 508.

Destatis 2018: [https://www.destatis.de/DE/ZahlenFakten/GesellschaftStaat/Bevoelkerung/Geburten/Tabellen/GeburtenZiffer.html, 08.01.2019]

Diabaté, Sabine et al. 2015: Familie XXL: Leitbild Kinderreichtum? In: Schneider, Norbert F.; Diabaté, Sabine; Ruckdeschel, Kerstin (Eds.): Familienleitbilder in Deutschland. Opladen/Berlin/Toronto: Verlag Barbara Budrich: 171-190.

Dorbritz, Jürgen 2008: Germany: Family Diversity with Low Actual and Desired Fertility. In: Demographic Research 19,17: 557-598 [doi: 10.4054/DemRes.2008.19.17]. 
Eidelman, Alexis 2013: L'imposition commune des couples maries ou pacsés: un avantage qui n'est pas systématique. In: Insee Analyses 9.

Eurostat 2017: [http://appsso.eurostat.ec.europa.eu/nui/show.do?dataset=demo_ fordager\&lang=de, 13.11.2018].

Fagnani, Jeanne 2002: Why Do French Women have More Children Than German Women? Family Policy and Attitudes Towards Child Care Outside the Home. In: Community, Work and Family 5,1: 103-120 [doi: 10.1080/1366880022010218].

Gauthier, Anne H. 2007: The Impact of Family Policies on Fertility in Industrialized Countries: A Review of the Literature. In: Population Research and Policy Review 26,3: 323346 [doi: 10.1007/s11113-007-9033-x].

Giesel, Katharina D. 2007: Leitbilder in den Sozialwissenschaften. Wiesbaden: VS Verlag für Sozialwissenschaften [doi: 10.1007/978-3-531-90731-4].

Hagewen, Kellie J.; Morgan, S. Philip 2005: Intended and Ideal Family Size in the United States, 1970-2002. In: Population Development Review 31,3: 507-527 [doi: 10.1111/j.1728-4457.2005.00081.x].

Hantrais, Linda 2004: Family Policy Matters: Responding to Family Change in Europe. Bristol: The Policy Press.

Hornung, Anne 2011. Avoir trois enfants et plus en France et en Allemagne: I'évolution démographique des familles nombreuses. In: Gouazé, Serge; Prat-Erkert, Cécile; Salles, Anne (Eds.): Les enjeux démographiques en France et en Allemagne: réalités et conséquences. Lille: Presses universitaires du Septentrion: 35-54 [doi: 10.4000/ books.septentrion.16008].

Insee Résultats 2018: La situation démographique en 2016. Etat civil et estimations de population [http://www.insee.fr, 08.01.2019]

Jaehrling, Karen et al. 2011: Arbeitsmarktintegration und sozioökonomische Situation von Alleinerziehenden. Ein empirischer Vergleich: Deutschland, Frankreich, Schweden, Vereinigtes Königreich. Berlin: BMAS - Bundesministerium für Arbeit und Soziales.

Klärner, Andreas 2015: The Low Importance of Marriage in Eastern Germany - Social Norms and the Role of Peoples' Perceptions of the Past. In: Demographic Research 33,9: 239-272 [doi: 10.4054/DemRes.2015.33.9].

Köppen, Katja; Mazuy, Magali; Toulemon, Laurent 2017: Childlessness in France. In: Kreyenfeld, Michaela; Konietza, Dirk (Eds.): Childlessness in Europe: Contexts, Causes, and Consequences. Cham: Springer: 77-95 [doi: 10.1007/978-3-319-44667-7_4].

Kreyenfeld, Michaela; Konietza, Dirk (Eds.) 2017: Childlessness in Europe: Contexts, Causes, and Consequences. Cham: Springer [doi: 10.1007/978-3-319-44667-7].

Liefbroer, Aart C. 2009: Changes in Family Size Intentions Across Young Adulthood: A Life-Course Perspective. In: European Journal of Population 25,4: 363-386 [doi: 10.1007/s10680-008-9173-7].

Liefbroer, Aart C.; Billari, Francesco C. 2010: Bringing Norms Back In: A Theoretical and Empirical Discussion of Their Importance for Understanding Demographic Behaviour. In: Population, space and place 16,4: 287-305 [doi: 10.1002/psp.552].

Liefbroer, Aart C.; Merz, Eva-Maria; Testa, Maria Rita 2015: Fertility-Related Norms Across Europe: A Multi-level Analysis. In: Philipov, Dimiter; Liefbroer, Aart C.; Klobas, Jane (Eds): Reproductive Decision-Making in a Macro-Micro Perspective. Dordrecht: Springer: 141-163 [doi: 10.1007/978-94-017-9401-5_6].

Luci-Greulich, Angela; Thévenon, Olivier 2013: The Impact of Family Policies on Fertility Trends in Developed Countries. In: European Journal of Population 29,4: 387-416 [doi: 10.1007/s10680-013-9295-4]. 
Lück, Detlev; Diabaté, Sabine; Ruckdeschel, Kerstin 2017: Cultural Conceptions of Family as Inhibitors of Change in Family Lives: The 'Leitbild' Approach. In: Cesnuitytè, Vida; Lück, Detlev; Widmer, Eric D. (Eds.): Family Continuity and Change. Basingstoke: Palgrave Macmillan: 61-86 [doi: 10.1057/978-1-137-59028-2_4].

Lück, Detlev et al. 2013: Familienleitbilder 2012. Methodenbericht zur Studie. Wiesbaden: Bundesinstitut für Bevölkerungsforschung.

McDonald, Peter 2005: Low Fertility and The State: The Efficacy of Policy. In: Population and Development Review 32,3: 485-510.

OECD 2016: Parental leave: Where are the fathers? Policy Brief March 2016.

Papon, Sylvain; Beaumel, Catherine 2018: Bilan démographique 2017. In: Insee Première 1683.

Périvier, Hélène 2004: Emploi des mères et garde des jeunes enfants en Europe. In: Revue de l'OFCE 90,3: 225-258 [doi: 10.3917/reof.090.0225].

Pfau-Effinger, Birgit 1996: Analyse internationaler Differenzen in der Erwerbsbeteiligung von Frauen. Theoretischer Rahmen und empirische Ergebnisse. In: Kölner Zeitschrift für Soziologie und Sozialpsychologie 48,3: 462-492.

Pfau-Effinger, Birgit 2004: Socio-historical Paths of The Male Breadwinner Model - An Explanation of Cross-national Differences. In: The British Journal of Sociology 55,3: 377-399 [doi: 10.1111/j.1468-4446.2004.00025.x].

Pilorin, Thomas; Legleye, Stephane 2018: Pondérations du panel ELIPSS. Working paper, CDSP, SciencesPo-CNRS, Janvier

Prioux, France 2007: L'évolution démographique récente en France: la fécondité à son plus haut niveau depuis plus de trente ans. In: Population-F 62,3: 489-532.

Rossier, Clémentine; Bernardi, Laura 2009: Social Interaction Effects on Fertility: Intentions and Behaviors. In: European Journal of Population 25,4: 467-485 [doi: 10.1007/ s10680-009-9203-0].

Ruckdeschel, Kerstin 2012: Comparing Desired Fertility and Perceptions of Motherhood in Germany and France. In: Demográfia 55,5 English Edition: 5-36.

Salles, Anne; Rossier, Clémentine; Brachet, Sara 2010: Understanding the Long Term Effects of Family Policies on Fertility: The Diffusion of Different Family Models in France and Germany. In: Demographic Research 22,34: 1057-1096 [doi: 10.4054/DemRes.2010.22.34].

Salles, Anne 2016: L'infécondité, une nouvelle normalité dans les parcours de vie en Allemagne aujourd'hui? In: Pennec, Sophie; Girard, Chantal; Sanderson, Jean-Paul (Eds.): Trajectoires et âges de la vie. Association Internationale des Démographes de Langue Française (AIDELF) [http://retro.erudit.org/livre/aidelf/2014/004341co.pdf, 14.11.2018].

Sobotka, Tomáš 2009: Sub-Replacement Fertility Intentions in Austria. In: European Journal of Population 25,4: 387-412 [doi: 10.1007/s10680-009-9183-0].

Sobotka, Tomáš 2008: The Diverse Faces of the Second Demographic Transition in Europe. In: Demographic Research 19: 171-224 [doi: 10.4054/DemRes.2008.19.8].

Statistisches Bundesamt 2017: Bevölkerung und Erwerbstätigkeit, Natürliche Bevölkerungsbewegung 2015. Fachserie 1, Reihe 1.1. Wiesbaden.

Statistisches Bundesamt 2009: Mikrozensus 2008. Neue Daten zur Kinderlosigkeit in Deutschland. Wiesbaden.

Toulemon, Laurent; Pailhé, Ariane; Rossier, Clémentine 2008: France: High and Stable Fertility. In: Demographic Research 19,16: 503-556 [doi: 10.4054/DemRes.2008.19.16]. 
Kerstin Ruckdeschel $(\bowtie)$, Dr. Sabine Diabaté. Federal Institute for Population Research. Wiesbaden, Germany.

E-mail: kerstin.ruckdeschel@bib.bund.de, sabine.diabate@bib.bund.de

URL: https://www.bib.bund.de/DE/Institut/Mitarbeiter/Ruckdeschel/Ruckdeschel.html

URL: https://www.bib.bund.de/DE/Institut/Mitarbeiter/Diabate/Diabate.html

Dr. Anne Salles: Université Paris-Sorbonne. Paris, France.

E-mail: anne.salles@paris-sorbonne.fr

URL: http://sirice.eu/membre/anne-salles

Dr. Laurent Toulemon, Dr. Arnaud Régnier-Loilier. Institut National d’Études

Démographiques. Paris, France. E-mail: toulemon@ined.fr, arnaud.regnier-loilier@ined.fr URL: https://www.ined.fr/en/research/researchers/Toulemon+Laurent

URL: https://www.ined.fr/en/research/researchers/R\%C3\%A9gnier-Loilier\%20Arnaud 


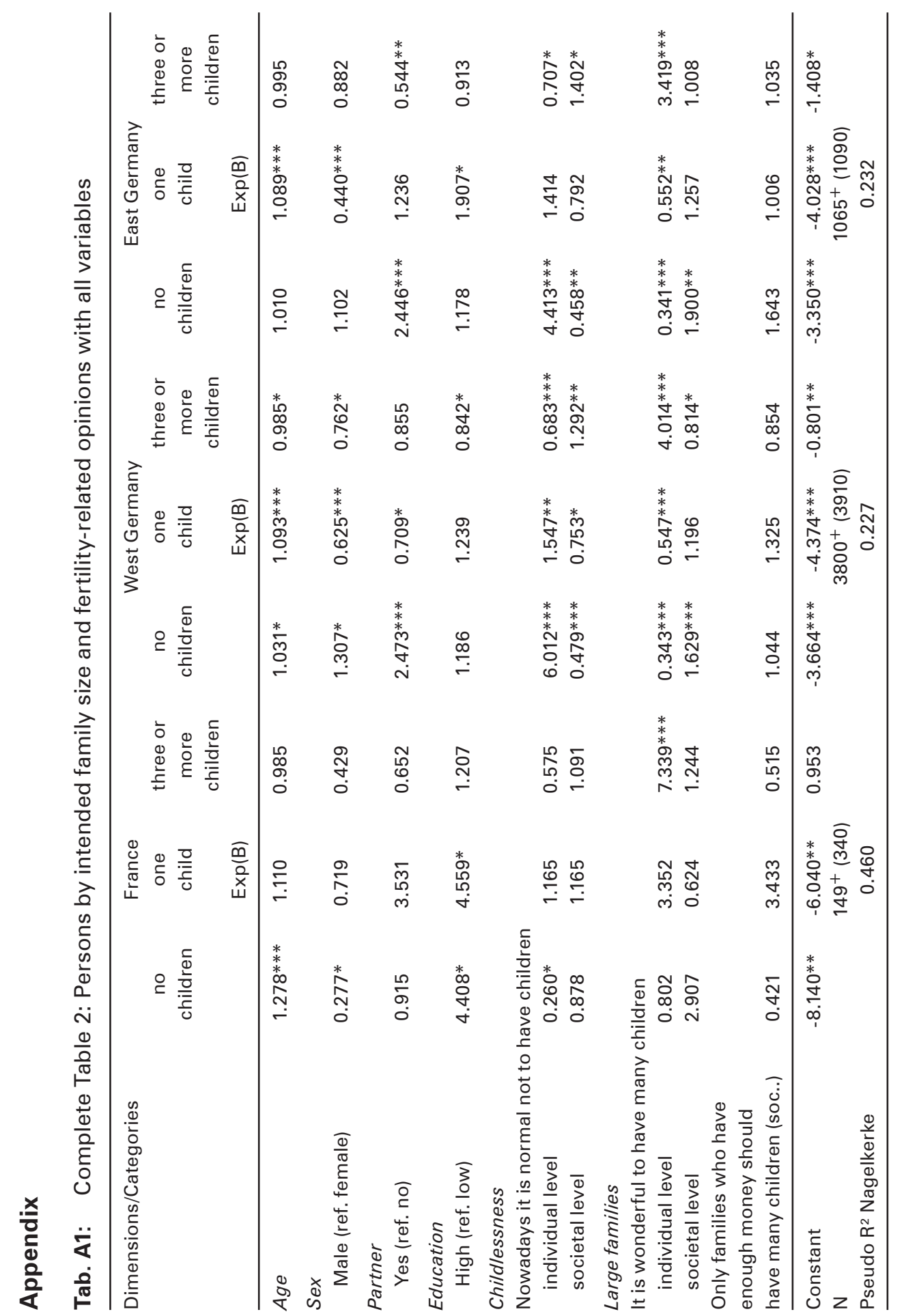




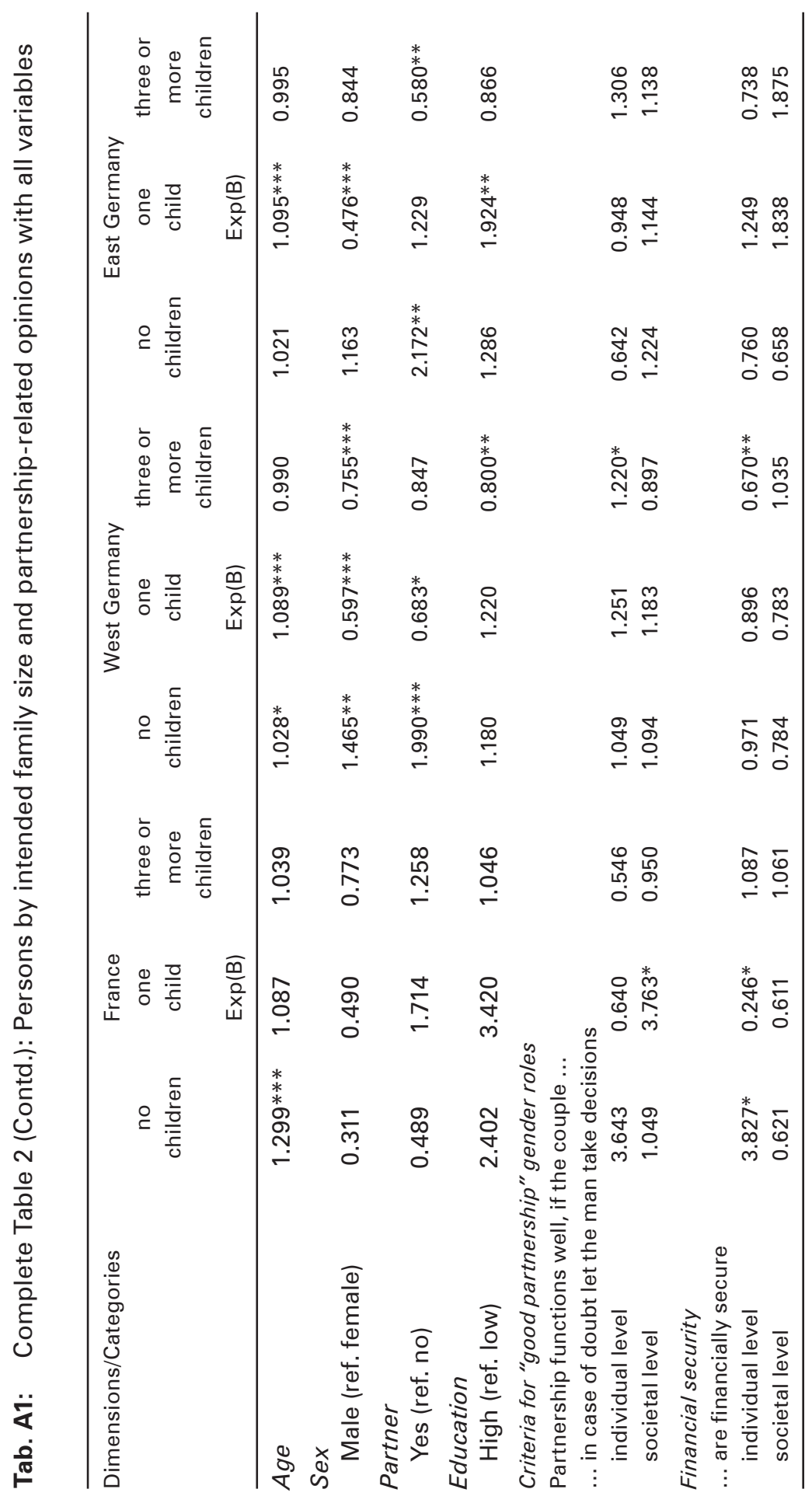


210 - Kerstin Ruckdeschel et al.

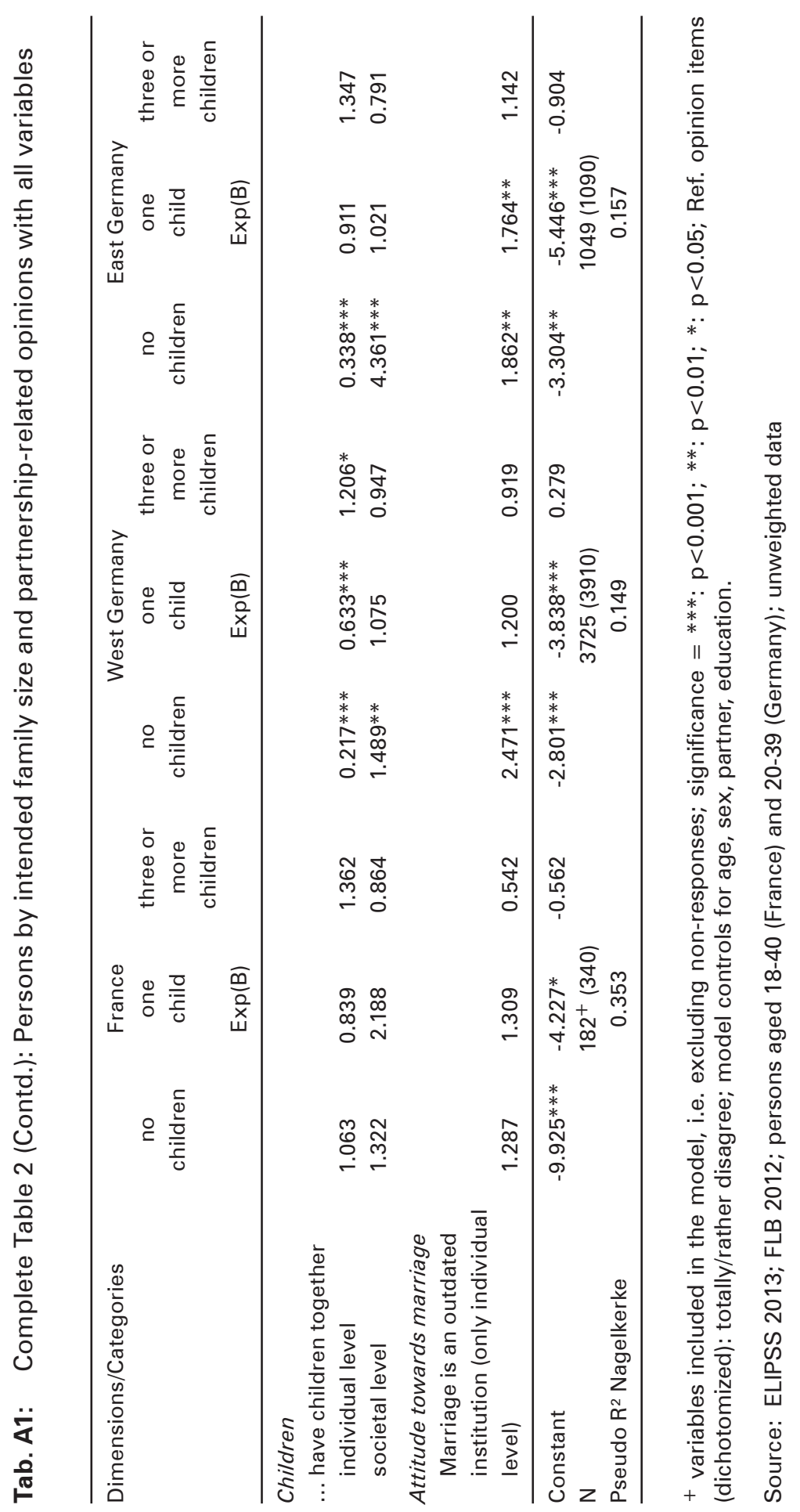




\section{Comparative Population Studies}

WWW.comparativepopulationstudies.de

ISSN: 1869-8980 (Print) - 1869-8999 (Internet)

\section{Published by}

Prof. Dr. Norbert F. Schneider

Federal Institute for Population Research D-65180 Wiesbaden / Germany

\section{(cc) BY-SA}

2018

\section{Managing Editor}

Dr. Katrin Schiefer

\section{Copy Editor}

Dr. Evelyn Grünheid

Dr. Katrin Schiefer

\section{Editorial Assistant}

Beatriz Feiler-Fuchs

Wiebke Hamann

\section{Layout \\ Beatriz Feiler-Fuchs \\ E-mail:cpos@bib.bund.de}

\section{Scientific Advisory Board}

Karsten Hank (Cologne)

Michaela Kreyenfeld (Berlin)

Marc Luy (Vienna)

Peter Preisendörfer (Mainz)

Nikola Sander (Wiesbaden)

Zsolt Spéder (Budapest)

Rainer Wehrhahn (Kiel)

\section{Board of Reviewers}

Martin Abraham (Erlangen)

Laura Bernardi (Lausanne)

Hansjörg Bucher (Bonn)

Claudia Diehl (Konstanz)

Andreas Diekmann (Zurich)

Gabriele Doblhammer-Reiter (Rostock)

Jürgen Dorbritz (Wiesbaden)

Anette Eva Fasang (Berlin)

E.-Jürgen Flöthmann (Bielefeld)

Alexia Fürnkranz-Prskawetz (Vienna)

Beat Fux (Salzburg)

Joshua Goldstein (Berkeley)

Sonja Haug (Regensburg)

Hill Kulu (Liverpool)

Aart C. Liefbroer (The Hague)

Kurt Lüscher (Konstanz)

Emma Lundholm (Umeå)

Nadja Milewski (Rostock)

Dimiter Philipov (Vienna)

Roland Rau (Rostock)

Tomáš Sobotka (Vienna)

Jeroen Spijker (Barcelona)

Olivier Thévenon (Paris)

Helga de Valk (Brussels)

Heike Trappe (Rostock)

Michael Wagner (Cologne) 